\title{
GnRH increases glucose transporter-1 expression and stimulates glucose uptake in the gonadotroph
}

\author{
Valerie M Harris', Sachin V Bendre ${ }^{3}$, Francina Gonzalez De Los Santos, Alemu Fite ${ }^{2}$, Ahmad El-Yaman \\ El-Dandachli, Lyazat Kurenbekova ${ }^{3}$, Abdul B Abou-Samra ${ }^{2}$ and Colleen Buggs-Saxton \\ Division of Endocrinology, Department of Pediatrics, Children's Hospital of Michigan, Wayne State University School of Medicine, 3901 Beaubien Boulevard, \\ 421 E. Canfield, Detroit, Michigan 48201-2119, USA \\ ${ }^{1}$ Department of Physiology, Wayne State University School of Medicine, 540 E, Canfield, Detroit, Michigan 48201, USA \\ ${ }^{2}$ Division of Endocrinology, Department of Internal Medicine, Wayne State University School of Medicine, 421 E. Canfield, Detroit, Michigan 48201, USA \\ ${ }^{3}$ Section of Endocrinology and Metabolism, Department of Pediatrics, Baylor College of Medicine, Texas Children's Hospital, Houston, Texas 77030, USA \\ (Correspondence should be addressed to C Buggs-Saxton; Email: cbuggs@med.wayne.edu)
}

\begin{abstract}
$\mathrm{GnRH}$ is the main regulator of the hypothalamic-pituitarygonadal $(\mathrm{H}-\mathrm{P}-\mathrm{G})$ axis. GnRH stimulates the pituitary gonadotroph to synthesize and secrete gonadotrophins (LH and FSH), and this effect of GnRH is dependent on the availability of glucose and other nutrients. Little is known about whether $\mathrm{GnRH}$ regulates glucose metabolism in the gonadotroph. This study examined the regulation of glucose transporters (Gluts) by GnRH in the L $\beta \mathrm{T} 2$ gonadotroph cell line. Using real-time PCR analysis, the expression of Glut1, -2, -4, and -8 was detected, but Glut1 mRNA expression level was more abundant than the mRNA expression levels of Glut2, -4 , and -8. After the treatment of L $\beta \mathrm{T} 2$ cells with GnRH, Glut1 mRNA expression was markedly induced, but there was no GnRH-induction of
\end{abstract}

Glut2, -4 , or -8 mRNA expression in L $\beta$ T2 cells. The effect of GnRH on Glut 1 mRNA expression is partly mediated by ERK activation. GnRH increased GLUT1 protein and stimulated GLUT1 translocation to the cell surface of L $\beta$ T2 cells. Glucose uptake assays were performed in L $\beta \mathrm{T} 2$ cells and showed that GnRH stimulates glucose uptake in the gonadotroph. Finally, exogenous treatment of mice with $\mathrm{GnRH}$ increased the expression of Glut1 but not the expression of Glut2, -4 , or -8 in the pituitary. Therefore, regulation of glucose metabolism by $\mathrm{GnRH}$ via changes in Gluts expression and subcellular location in the pituitary gonadotroph reveals a novel response of the gonadotroph to $\mathrm{GnRH}$.

Journal of Endocrinology (2012) 212, 139-147

\section{Introduction}

GnRH is the master regulator of the hypothalamic-pituitarygonadal $(\mathrm{H}-\mathrm{P}-\mathrm{G})$ reproductive axis. It binds to receptors in the pituitary gonadotroph cell to increase the synthesis and secretion of LH and FSH, both of which stimulate the ovary and testis to release sex steroids and induce oocyte maturation and spermatogenesis, respectively. Glucose is an important fuel for hypothalamic regulation of the reproductive axis. It is well known that across species a reduction in glucose availability by caloric restriction or fasting impairs LH secretion, and subsequent treatment with glucose or food restores pulsatile LH secretion in different species (Foster \& Olster 1985, Cagampang et al. 1991, Cameron et al. 1991, Schreihofer et al. 1993, 1996, Murahashi et al. 1996, Nagatani et al. 1996, 2000). Additional studies showed that impairing glucose availability by infusing 2-deoxy-D-glucose or insulin in ovariectomized goats decreased GnRH pulse frequency, but subsequent infusion of glucose together with insulin restored normal GnRH pulse frequency (Ohkura et al. 2004).
In addition, a study using inhibitors of glycolysis showed that GnRH-stimulated release of LH was impaired (Sen et al. 1979, Howland 1980). There is limited information about glucose effects and mediators of glucose sensing in the pituitary gonadotroph. One study showed that acute hyperglycemia impaired GnRH-stimulated $\mathrm{LH}$ secretion in primary cultured porcine pituitary cells (Barb et al. 1995). Another study showed that fasting rats for $24 \mathrm{~h}$ reduced the expression of LH mRNA and other pituitary hormones as well as pituitary leptin expression (Crane et al. 2007). When fasted rats were given $10 \%$ glucose water for $24 \mathrm{~h}$, there was restoration of both glucose and LH levels as well as pituitary leptin. In addition, treatment of fasted rats with leptin was shown to increase LH levels indicating that leptin may be important for glucose sensing in the gonadotroph. Together, these studies show that glucose is an important energy fuel required for normal regulation of the reproductive axis at both the level of hypothalamic GnRH neurons and the pituitary gonadotroph. Still further studies are needed to understand components of glucose sensing in 
the gonadotroph and whether GnRH regulates glucose metabolism in the gonadotroph.

Glucose enters cells via the solute carrier family-2 (SLC-2) proteins, which are also commonly referred to as glucose transporters (GLUTs; Mueckler 1994, Uldry \& Thorens 2004). There are over 13 GLUTs, which share a common overall structure but differ in their primary sequences, tissue expression, and subcellular localization. Some GLUTs have well characterized roles in glucose metabolism in specific tissues. In muscle and adipose tissues, insulin stimulates glucose uptake by inducing translocation of GLUT4 from intracellular compartment to the plasma membrane (Hajduch et al. 1995, Haney et al. 1995, Kandror et al. 1995a,b, Marsh et al. 1995). In the pancreatic $\beta$-cell, GLUT2 is important for glucose-stimulated insulin secretion (Mueckler 1994, Stenbit et al. 1997, Guillam et al. 2000, Uldry \& Thorens 2004). GLUT1, which is ubiquitously expressed, is primarily responsible for basal glucose uptake in most tissues especially in endothelial cells of the blood-brain barrier (Maher et al. 1994). In cardiac muscle cells, insulin modulates glucose metabolism by inducing GLUT4 and GLUT1-translocation (Rett et al. 1996, Egert et al. 1999). The role of GLUTs in the reproductive axis has been examined in the ovary and endometrium. In the oocyte and granulosa cell, GLUT1 is regulated by IGF1 and estradiol (Zhou et al. 2000). In the endometrial stromal cells, Glut1 expression is regulated by estradiol and progesterone (Frolova et al. 2009). There is very limited information about the expression of Gluts in the pituitary gonadotroph. Microarray analysis of $\mathrm{GnRH}-$ stimulated gene expression in L $\beta$ T2 gonadotroph cells detected an increase in Glut1 expression but not other Gluts (Wurmbach et al. 2001, Mazhawidza et al. 2006). In this study, we report for the first time that several Gluts are expressed in L $\beta T 2$ gonadotroph cells, but GnRH markedly induces Glut1 expression and translocation to the plasma membrane and increases glucose uptake. GnRH induction of Glut1 expression and glucose utilization in the pituitary gonadotroph provides new insights into the coordinated regulation of reproductive function and glucose metabolism by $\mathrm{GnRH}$.

\section{Materials and Methods}

\section{Reagents}

GnRH and actinomycin D were purchased from SigmaAldrich. Cell culture media were purchased from Mediatech, Inc. (Manassas, VA, USA) and supplemented with penicillinstreptomycin solution (Hyclone Laboratories, South Logan, UT, USA) and $10 \%$ fetal bovine serum (Gemini Bio-Products, West Sacramento, CA, USA), Matrigel (BD Biosciences, Bedford, MA, USA). Other reagents for realtime PCR are as follows: DNase I (Invitrogen, Co.), High Capacity cDNA Reverse Transcript Kit (Applied Biosystems, Foster City, CA, USA), TRIzol (Invitrogen Co.); Taqman
Gene Expression Assays (Applied Biosystems), other molecular biology reagents are as follows: DMSO (Mediatech, Inc.), Ethanol (Sigma-Aldrich), U0126 (Bis[amino[(2aminophenyl)thio]methylene]butanedinitrile (Invitrogen, Co.), PBS (Fisher Scientific, Fair Lawn, NJ, USA), SDS (Fisher Scientific), Nonidet P40 (Calbiochem, LaJolla, CA, USA), Complete Protease Inhibitor cocktail (Roche Diagnostics), polyclonal rabbit GLUT1 and -8 IgG (Abcam, Inc., Cambridge, MA, USA), GAPDH (Chemicon-Millipore Co., Danvers, MA, USA), polyclonal rabbit $\alpha$ Tubulin IgG and goat anti-rabbit IgG-HRP (Santa Cruz Biotechnology, Santa Cruz, CA, USA), goat anti-mouse IgG-HRP (ChemiconMillipore Co.), paraformaldehyde (Electron Microscopy Sciences, Hatfield, PA, USA), rabbit isotype $\operatorname{IgG}$ (Invitrogen, Co.), SuperSignal West Pico Chemiluminescent Substrate (Thermo Scientific, Rockford, IL, USA), GLUT1 peptide (Thermo Scientific), Alexa Fluor 633 goat-anti-rabbit (Invitrogen Co.), 4',6-diamidino-2-phenylindole (DAPI; Invitrogen Co.), Coomassie Plus Protein Assay Reagent (Thermo Scientific), Cytochalasin B (Sigma-Aldrich), with 2-deoxy-D-[3H]-glucose (Perkin-Elmer, Waltham, MA, USA), other reagents including calcium chloride, magnesium sulfate, HEPES, Tris base, sodium chloride, SDS, potassium chloride, and Tween 20, methanol, ethanol, Tritox-X100, BSA-fraction V were purchased from Fisher Scientific, and LH EIA Kit was purchased from Cayman Chemical Company (Ann Arbor, MI, USA).

\section{Animals}

Female and male C57BL/6J mice were obtained from the Jackson Laboratory (Bar Harbor, ME, USA). They were housed four or ten mice per cage, maintained on a 14:10 light-dark cycles and allowed ad libitum access to food and water. Prepubertal mice (3- to 4-week-old) were given exogenous $\mathrm{GnRH} 400 \mathrm{ng} / \mathrm{kg}$ (LHRH Sigma) or vehicle $(0.9 \% \mathrm{NaCl})$ via i.p. injection as previously described (Chappell et al. 1999). Approximately 60-90 min after GnRH administration, mice were killed by isoflurane inhalation followed by cervical dislocation. Blood was then collected via cardiac puncture to measure hormone levels, and the pituitary gland was isolated for RNA extraction as described below to measure changes in gene expression. All protocols were conducted in accord with the National Institutes of Health guide for the care and use of laboratory animals and were approved by the Committees of Animal Care and Use of Wayne State University.

\section{LH assay}

Blood collected from mice was treated with GnRH or vehicle and centrifuged at $12000 \boldsymbol{g}$ for $15 \mathrm{~min}$, and then serum was transferred to clean tubes and stored at $-20^{\circ} \mathrm{C}$ until used in assay. LH EIA Kit was used to measure LH in serum $(50 \mu \mathrm{l}$ of serum/mouse sample) from mice treated with vehicle or exogenous $\mathrm{GnRH}$ according to assay protocol by measuring 
the optical density (OD) at $450 \mathrm{~nm}$ of serum samples and $\mathrm{LH}$ standards provided in kit. LH serum concentrations $(\mathrm{mIU} / \mathrm{ml})$ in samples were determined using ReaderFit (software at www.Readerfit.com) to plot OD vs concentration for standards. Fold effects were determined by normalizing GnRH-induced LH levels to vehicle-induced LH levels.

\section{GnRH stimulation studies}

L $\beta$ T2 cells (Thomas et al. 1996, Turgeon et al. 1996) (approximately at $75 \%$ confluency or $1 \times 10^{6}$ cells/well in a 6 -well plate) were grown in media containing $4.5 \mathrm{~g} / 1$ glucose with sodium pyruvate supplemented penicillin-streptomycin solution, and $10 \%$ fetal bovine serum, and then treated with $10 \mathrm{nM} \mathrm{GnRH}$ for 2, 4, and $8 \mathrm{~h}$. To perform dose-response studies, L $\beta$ T2 cells were stimulated with GnRH $(0 \cdot 1-100 \mathrm{nM})$ for $2 \mathrm{~h}$, and total RNA was isolated using TRIzol Reagent. Total RNA $(1 \mu \mathrm{g})$ was treated with DNase I for time course and dose-response studies, and then cDNA was synthesized using the High Capacity cDNA Reverse Transcript Kit.

To perform studies with inhibitors, $\mathrm{L} \beta \mathrm{T} 2$ cells were treated with $10 \mu \mathrm{g} / \mathrm{ml}$ of actinomycin D or DMSO as its vehicle control $30 \mathrm{~min}$ prior to the addition of GnRH $(10 \mathrm{nM})$. Two hours after the addition of GnRH, total RNA from cells was prepared using the TRIzol Reagent and total RNA $(2 \mu \mathrm{g})$ was used to synthesize cDNA as described above. For MAPK inhibitor studies, $10 \mu \mathrm{M}$ U0126 (Bis[amino[(2aminophenyl)thio]methylene]butanedinitrile was added to cells $1 \mathrm{~h}$ prior to the addition of GnRH (10 nM). Two hours after the addition of GnRH, total RNA from cells was prepared using the TRIzol Reagent and total RNA $(2 \mu \mathrm{g})$ was used to synthesize cDNA as described above.

\section{Real-time PCR quantification of Gluts}

The cDNA (representing 50 or 100 ng of starting RNA) was subsequently used for real-time PCR analyses via Taqman Gene Expression Assays for Glut1 (Mn00441473_m1), Glut2 (Mm00446224_m1), Glut4 (Mm01245502_m1), Glut8 (Mn00444634_m1), and Tbp (Mm00446973_m1). PCRs were conducted using the StepOne Plus Real-time PCR System (Applied Biosystems). Serial 10-fold dilutions of a representative sample were used initially to assess that the efficiency of each Taqman gene assay was $90-110 \%$. Cycle threshold $\left(C_{\mathrm{t}}\right)$ was obtained for each sample. A corrected $C_{\mathrm{t}}\left(\Delta C_{\mathrm{t}}\right)$ was calculated by subtracting the $T b p C_{\mathrm{t}}$ from the target genes (Glut1, -2, -4, and -8) $C_{\mathrm{t}}$ for each sample. Relative differences from the control sample were then calculated by using the formula: fold change $=2^{\wedge}$ (Control $\Delta C_{\mathrm{t}}-$ Sample $\Delta C_{\mathrm{t}}$ ).

\section{Western blot analysis}

Whole cell extracts were prepared from L $\beta \mathrm{T} 2$ cells treated with vehicle or GnRH (30 nM) for 2, 4, and 8 h using RIPA buffer containing $1 \times$ PBS, $0 \cdot 1 \%$ SDS, and $1 \%$ Nonidet P40 with $1 \times$ Complete Protease Inhibitor cocktail. Protein concentration was determined by using Coomassie Plus Protein Assay Reagent, and western blot analysis was performed on protein extracts $(50 \mu \mathrm{g} / \mathrm{lane})$ with a polyclonal antibody against GLUT1, -8 , GAPDH, and $\alpha$ Tubulin were used. Immunodetection of protein was performed using SuperSignal West Pico chemiluminescent reagent. Using the AlphaEase FC software Program, densitometric analysis was performed on autoradiographs of scanned images from western blot analysis of three sets of protein extracts for each time point (no GnRH and GnRH at 2, 4, and $8 \mathrm{~h}$ ).

\section{Immunostaining of $L \beta T 2$ cells and confocal microscopy}

L $\beta$ T2 cells were grown on Matrigel-coated cover slips and stimulated with $\mathrm{GnRH}(100 \mathrm{nM})$ for 2, 4, and $8 \mathrm{~h}$. Cells were fixed with $2 \%$ paraformaldehyde for $30 \mathrm{~min}$ and methanolethanol (50-50), and then permeabilized with $0.5 \%$ Triton-X for $10 \mathrm{~min}$ prior to blocking (10\% BSA) for $60 \mathrm{~min}$ at room temperature (RT). Primary antibodies, rabbit-polyclonal GLUT1, and rabbit isotype IgG diluted 1:200 were applied overnight at $4{ }^{\circ} \mathrm{C}$, while secondary antibody and Alexa Fluor 633 goat-anti-rabbit diluted 1:500 were incubated for $1 \mathrm{~h}$ the next day. After washing with PBS, mounting media with DAPI (a nuclear marker) was added to coverslips prior to mounting on slides. Slides were viewed with the Leica TCS SP5 Laser-scanning confocal microscope viewed at $63 \times$ magnification with oil using software LAS_AF version 2.3.1.

\section{Glucose uptake assays}

L $\beta$ T2 cells were grown in normal media $(4.5 \mathrm{~g} / 1$ glucose with sodium pyruvate) supplemented with antibiotics and 10\% fetal bovine serum in 24-well plates overnight. The next morning media were replenished and cells were stimulated with GnRH (100 nM) for $4 \mathrm{~h}$. Cytochalasin B at $20 \mu \mathrm{M}$, an inhibitor of glucose transport ( $\mathrm{Lu}$ et al. 1997), was added $30 \mathrm{~min}$ prior to glucose uptake analysis in control cells and cells were treated with GnRH. Glucose uptake assays were performed with 2-deoxy-D-[3H]-glucose radioisotopic technique as previously described (Kozma et al. 1993). GnRHtreated cells and controls were aspirated, washed, and incubated with HEPES-buffered solution $(50 \mathrm{mM}$ HEPES, $\mathrm{pH} 7 \cdot 4,136 \mathrm{mM}$ sodium chloride $4.7 \mathrm{mM}$ potassium chloride, $1.25 \mathrm{mM}$ magnesium sulfate, and $1.25 \mathrm{mM}$ calcium chloride) containing $0.5 \mu \mathrm{Ci} / \mathrm{ml}$ 2-deoxy-D-[3H]-glucose for $10 \mathrm{~min}$. Glucose transport was stopped by washing three times with ice-cold PBS. Cells were lyzed with $1 \%$ SDS, and cell-associated radioactivity was determined by scintillation counting. To determine the specific glucose uptake, counts per minute (CPM) in the presence of cytochalasin $\mathrm{B}$ was subtracted from each corresponding time point and then normalized for DNA content. GnRH-stimulated fold effects were calculated by dividing GnRH-stimulated glucose uptake by basal glucose uptake (in the absence of GnRH). 


\section{Statistical analysis}

Each data point represents the mean value + S.E.M. of at least three measurements obtained in three or more repeated studies with the same experimental conditions. Significance was determined at $P<0.05$ by analyzing data using ANOVA followed by Bonferroni post hoc test or Student's $t$-test analysis using Prism (GraphPad Software, Inc., San Diego, CA, USA) or Mann-Whitney $U$ test.

\section{Results}

Gluts are expressed in L $\beta T 2$ gonadotroph cells and murine pituitary

Since others have shown by microarray analysis that GnRH increases Glut1 expression (Wurmbach et al. 2001, Mazhawidza et al. 2006), we compared the relative basal expression of Glut 1 to the basal expression of other Gluts in L $\beta$ T2 gonadotroph cells using real-time PCR analysis. The basal expression of Glut1 was 1.34-fold, which was
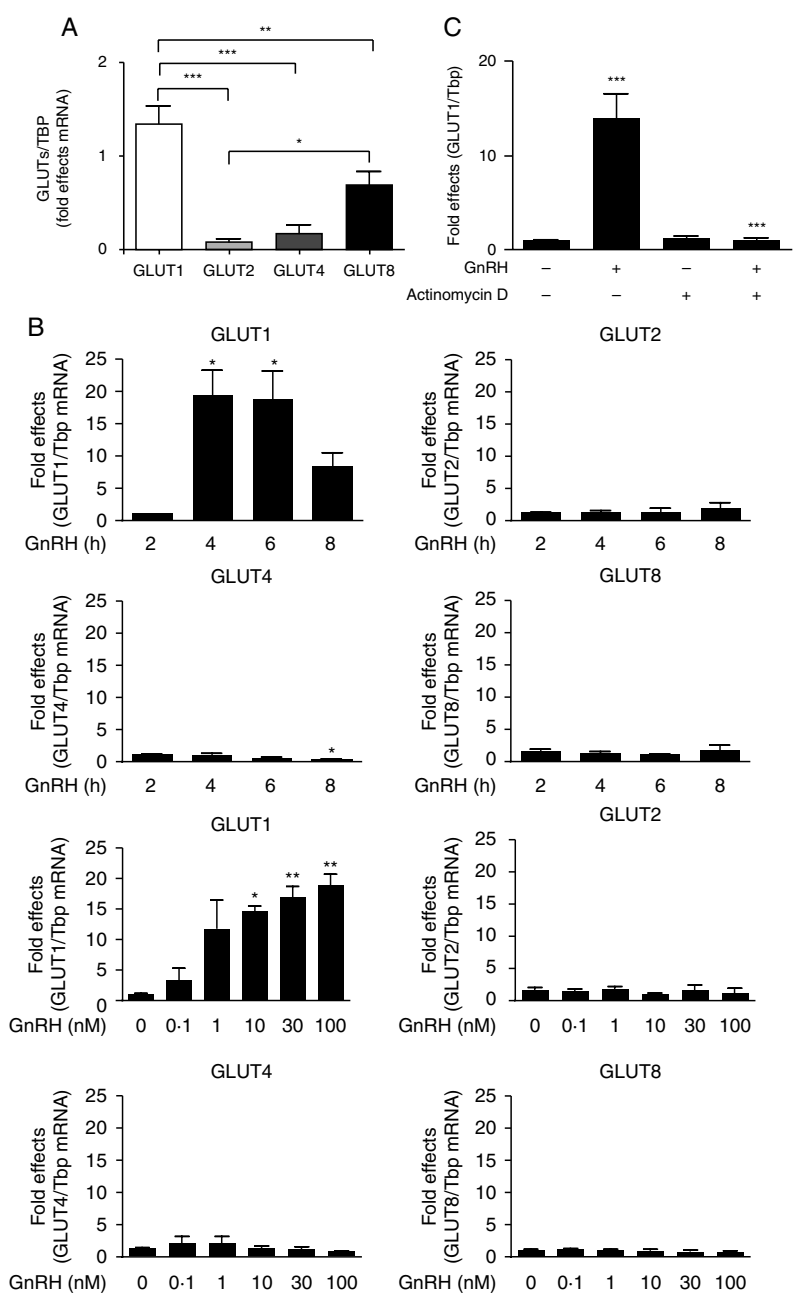

significantly higher than the basal expression of Glut2 (0·1-fold), Glut4 (0.2-fold), and Glut8 (0.7-fold) (Fig. 1A, $P<0.001$ for Glut 1 vs Glut2 and -4 and $P<0.01$ for Glut 1 vs Glut8). The basal expression of Glut8 was significantly higher than the basal expression of Glut2 (Fig. 1A, $P<0 \cdot 05$ ).

We next investigated whether GnRH regulates Glut1 and other Gluts (Glut2, -4, and -8) mRNA expression in L $\beta \mathrm{T} 2$ cells. Using real-time PCR analysis, we found that $\mathrm{GnRH}$ increased Glut $1 \mathrm{mRNA}$ expression 19.4-fold at $2 \mathrm{~h}, 18 \cdot 8$-fold at $4 \mathrm{~h}$, and 8.3 -fold at $8 \mathrm{~h}$, respectively (Fig. $1 \mathrm{~B}, P<0.05$ no GnRH $(0 \mathrm{~h})$ vs GnRH at $2 \mathrm{~h}$ and $P<0.05$ no GnRH $(0 \mathrm{~h})$ vs GnRH at 4 h). In contrast, GnRH decreased Glut 4 mRNA expression (Fig. 1B, $P<0 \cdot 05$, no GnRH $(0 \mathrm{~h})$ vs GnRH at $8 \mathrm{~h}$ ). $\mathrm{GnRH}$ had no significant effect on Glut 2 or -8 mRNA expression (Fig. 1B). Since the peak effect of GnRH on Glut1 expression occurred with GnRH treatment at $2 \mathrm{~h}$, dose-response studies were performed with increasing concentrations of GnRH $(0 \cdot 1-100 \mathrm{nM})$ at $2 \mathrm{~h}$. Glut 1 mRNA expression increased $3 \cdot 3$-fold at $0 \cdot 1 \mathrm{nM}, 11 \cdot 8$-fold at $1 \mathrm{nM}, 14 \cdot 6$-fold at $10 \mathrm{nM}, 16 \cdot 8$-fold at $30 \mathrm{nM}$, and $18 \cdot 8$ fold at $100 \mathrm{nM} \mathrm{GnRH} \mathrm{(Fig.} \mathrm{1B,} P<0 \cdot 05$ no GnRH vs GnRH at $10 \mathrm{nM}$ and $P<0 \cdot 01$, no GnRH vs GnRH at 30 or $100 \mathrm{nM}$ ). GnRH dose-response studies showed no significant changes in the expression of Glut2, -4 , or -8 mRNA levels (Fig. 1B).

To further investigate mechanism by which GnRH increases Glut1 mRNA expression additional studies were performed with inhibitors of transcription and MAPK

Figure 1 Regulation of glucose transporters by GnRH in L $\beta T 2$ cells. (A) RNA was isolated from $L \beta T 2$ cells and real-time PCR analysis was performed. Basal expression of Glut1, -2, -4, and -8 was normalized to basal expression of Tbp and then fold effects were determined by comparing basal expression of Glut1 (white bar), Glut2 (light gray bar), Glut4 (dark gray bar), and Glut8 (black bar) to the basal expression of Glut1. Each bar represents the mean \pm S.E.M. of six experiments (and each experiment contained three samples that were also averaged) as shown in the graph. (B) L $\beta T 2$ cells were stimulated with $\mathrm{GnRH}\left(10 \mathrm{M}^{-9}\right)$ for $2-8 \mathrm{~h}$ and total RNA was isolated to make cDNA and then subjected to real-time PCR analysis. GnRH-treated cells $(2-8 \mathrm{~h})$ were compared to untreated cells $(0 \mathrm{~h})$ and fold effects of Glut 1, $-2,-4$, and -8 gene expression were determined after normalization with Tbp expression. $\mathrm{L} \beta \mathrm{T} 2$ cells were stimulated with $\mathrm{GnRH}\left(0 \cdot 1-100 \mathrm{M}^{-9}\right)$ for $2 \mathrm{~h}$ and total RNA was isolated to make cDNA and then subjected to real-time PCR analysis. Fold effects of Glut1, -2, -4, and -8 gene expression in $\mathrm{GnRH}$-treated cells were compared to untreated cells and were determined after normalization with Tbp expression. (C) $L \beta T 2$ cells were treated with treated with actinomycin $\mathrm{D}(10 \mu \mathrm{g} / \mathrm{ml}) 30 \mathrm{~min}$ prior to adding $\mathrm{GnRH}\left(10 \mathrm{M}^{-9}\right)$. Two hours after the addition of $\mathrm{GnRH}$, total RNA was isolated to make cDNA, which was then subjected to real-time PCR analysis. After normalization with Tbp expression, fold effects were determined by comparing Glut1 mRNA expression induced by $\mathrm{GnRH}(+/-$ actinomycin D) to Glut1 mRNA expression in cells in the absence of $\mathrm{GnRH}$ or actinomycin D. Each graph contains bars that represent the mean \pm s.E.M. of three experiments (and each experiment contained three samples per treatment condition that were also averaged). Significance was determined using ANOVA analysis with Bonferroni post hoc test $* P<0 \cdot 05$, $* * P<0 \cdot 01 ; * * * P<0 \cdot 001$. 


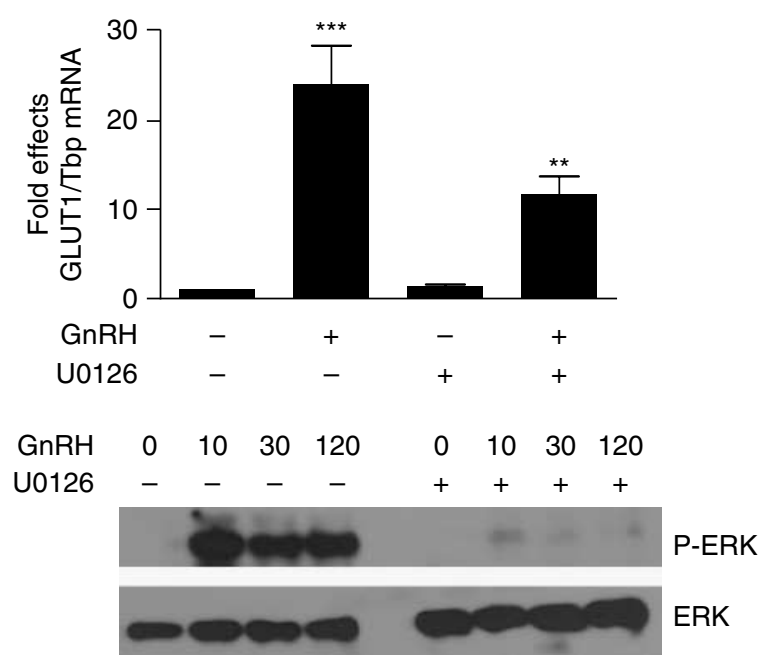

Figure 2 GnRH-stimulated Glut1 mRNA expression requires transcriptional activation and ERK activation. (A) $L \beta T 2$ cells were treated with $\cup 0126\left(10 \mathrm{M}^{-6}\right) 60$ min prior to adding $\mathrm{GnRH}\left(10 \mathrm{M}^{-9}\right)$. Two hours after the addition of $\mathrm{GnRH}$, total RNA was isolated to make cDNA, which was then subjected to real-time PCR analysis. After normalization with Tbp expression, fold effects of Glut1 expression were determined by comparing Glut1 mRNA expression induced by $\mathrm{GnRH}+/-\mathrm{U} 0126$ to the expression of Glut1 in cells in the absence of $\mathrm{GnRH}$ or U0126. Each graph contains bars that represent the mean \pm S.E.M. of three or more experiments (and each experiment contained three samples per treatment condition that were also averaged). Significance was determined using ANOVA analysis with Bonferroni post hoc test ${ }^{* *} P<0 \cdot 01$; ${ }^{* * *} P<0 \cdot 001$. (B) L $\mathrm{L} T 2$ cells were treated with $\cup 0126\left(10 \mathrm{M}^{-6}\right) 60$ min prior to adding $\mathrm{GnRH}\left(10 \mathrm{M}^{-9}\right)$ for 10, 30, or $120 \mathrm{~min}$ and then whole extracts were made. Extracts were used in western blot analysis with phosphorylated ERK and ERK antibodies as shown. The autoradiograph of a representative experiment is shown.

signaling. Cells were pretreated with actinomycin D, an inhibitor of transcription, $30 \mathrm{~min}$ prior to the addition of GnRH $(10 \mathrm{nM})$ and then $2 \mathrm{~h}$ later changes in Glut 1 mRNA expression were examined by real-time PCR analysis. As seen previously, Glut $1 \mathrm{mRNA}$ expression was increased by 18.8-fold by GnRH alone (Fig. 1C, $P<0 \cdot 001$, untreated (no $\mathrm{GnRH}$ ) vs GnRH treated). In the presence of actinomycin D, induction of Glut1 expression by $\mathrm{GnRH}$ was completely blocked, but actinomycin $\mathrm{D}$ alone did not inhibit basal expression of Glut 1 mRNA (Fig. 1C, $P<0.001 \mathrm{GnRH}$ without actinomycin D vs GnRH with actinomycin D).

We next investigated signaling pathways involved in mediating effects of GnRH on Glut1 gene expression. GnRH is known to activate several MAPK pathways in gonadotroph cells (Kraus et al. 2001, Liu et al. 2002). We examined whether the signaling pathway that activates the ERK, one of the GnRH-activated MAPKs, is important for mediating effects of GnRH on Glut 1 mRNA gene expression. Pretreatment with U0126, an inhibitor of ERK activation, blocked GnRH-stimulated Glut1 mRNA expression by $48 \%$ (Fig. 2A, $P<0 \cdot 01$, GnRH with vehicle vs GnRH with U0126) and blocked GnRH-induced phosphorylation of ERK (Fig. 2B).
GnRH increases GLUT1 protein in L $\beta T 2$ cells

Since GnRH stimulates Glut1 mRNA levels, the effect of GnRH on GLUTs protein content in the gonadotroph was examined. Western blot analysis was performed with whole cell extracts isolated from $\mathrm{L} \beta \mathrm{T} 2$ cells treated with $\mathrm{GnRH}$ $(30 \mathrm{nM})$. Several GLUT1 protein bands were detected between 37 and $50 \mathrm{kDa}$ and these bands were not detected in the presence of excess GLUT1 peptide (data not shown). GnRH increased GLUT1 protein level by $3 \cdot 5$-fold at $4 \mathrm{~h}$ and 6.6-fold at $8 \mathrm{~h}$ (Fig. 3A, lane 1 vs lanes $2-4$ and Fig. 3B, $P<0 \cdot 05$ no GnRH $(0 \mathrm{~h})$ vs GnRH at $8 \mathrm{~h}$ ). The effect of GnRH on GLUT8 protein level was not statistically significant (Fig. 3A and B). Western blot analysis did not detect GLUT2 or -4 protein in $\mathrm{L} \beta \mathrm{T} 2$ whole cell protein extracts in the absence or presence of GnRH treatment (data not shown).

To further examine the regulation of GLUT1 protein by GnRH, immunofluorescent analysis with confocal microscopy was performed to examine the subcellular location of GLUT1 protein in GnRH-treated L $\beta$ T2 cells (Fig. 4). In the absence of GnRH, GLUT1 was diffusely distributed in the cytosol and perinuclear region of the cell (Fig. 4A, untreated cells, no GnRH). In the presence of GnRH, GLUT1 protein increased at the cell surface in a time-dependent manner that is clearly seen at $4-8 \mathrm{~h}$ after GnRH treatment (Fig. 4A, no GnRH vs $4 \mathrm{~B}-\mathrm{D}$, GnRH 2-8 h). In contrast, GnRH showed a transient increase in GLUT8 protein in the perinuclear region of the cell (Fig. 4E, no GnRH vs $4 \mathrm{~F}-\mathrm{H}$, GnRH $2-8 \mathrm{~h}$ ). These results show that in L $\beta$ T2 cells GnRH increases the detection of GLUT1 at the cell surface, indicating that GnRH stimulates GLUT1
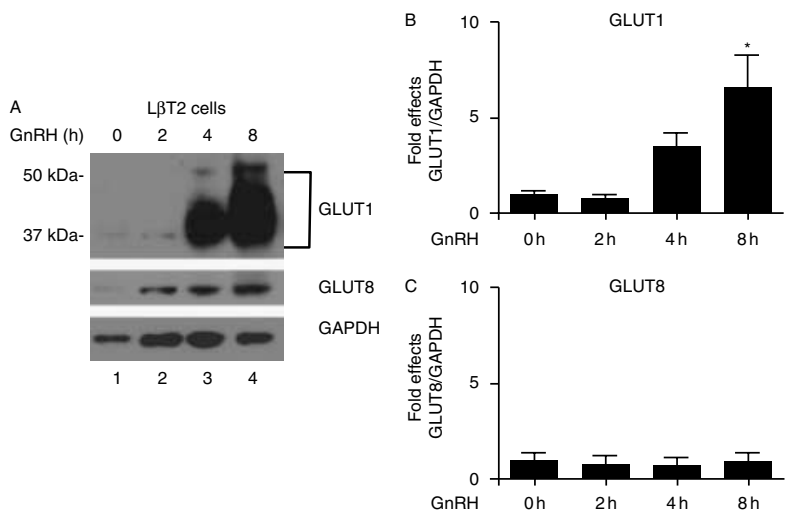

Figure $3 \mathrm{GnRH}$ increases GLUT1 protein expression in L $\beta$ T2 cells. (A) Whole cell extracts $\left(50 \mathrm{gm}^{-6}\right)$ were prepared from L $\beta T 2$ cells after stimulation with $\mathrm{GnRH}\left(30 \mathrm{M}^{-9}\right)$ for $2 \mathrm{~h}$ (lane 2), $4 \mathrm{~h}$ (lane 3), and $8 \mathrm{~h}$ (lane 4 ) or no GnRH (lane 1 ) and western blot analysis was performed with GLUT1, -8, and GAPDH antibodies. A picture of a representative autoradiograph is shown. (B) Densitometry analysis of GnRH-induced GLUT1 and -8 protein content normalized for GAPDH protein content was performed with three sets of extracts for each time point and the mean \pm S.E.M. is shown in graphs. Significance was determined using ANOVA with Bonferroni post hoc test. ${ }^{*} P<0 \cdot 05$ no $\mathrm{GnRH}(0 \mathrm{~h})$ compared to $\mathrm{GnRH}$ at $8 \mathrm{~h}$. 
translocation in L $\beta$ T2 cells. Competition studies with GLUT1 peptide blocked the detection of GLUT1 immunofluorescence (data not shown).

\section{GnRH stimulates glucose uptake in L $\beta T 2$ cells}

Since GnRH increases GLUT1 protein levels and detection of GLUT1 at the cell surface, we investigated whether GnRH stimulates glucose uptake in L $\beta$ T2 cells. Glucose uptake assays were performed with 2 -deoxy-D-[3H]-glucose. L $\beta$ T2 cells were grown in normal medium and then stimulated with GnRH $(100 \mathrm{nM})$ for $4 \mathrm{~h}$. Compared to basal glucose uptake, GnRH increased glucose uptake by $1 \cdot 8$-fold in L $\beta$ T2 cells (Fig. 5, $P<0.05$ ). This increase in glucose uptake corresponded to the time-dependent increased detection of GnRH-stimulated GLUT1 protein at the cell surface (Fig. 4C, 4 h GnRH). Therefore, GnRH stimulates glucose uptake in L $\beta \mathrm{T} 2$ cells.

\section{$\mathrm{GnRH}$ regulates GLUT1 gene expression in the murine} pituitary gland in vivo

Since our studies were conducted using the L $\beta$ T2 cell line, we further investigated whether GnRH induced upregulation of Glut1 expression in gonadotrophs in vivo. We treated 3to 4-week-old C57BL/6J mice with exogenous GnRH (LHRH) or vehicle and then collected blood and the pituitary gland 60-90 min after injection of GnRH or vehicle. Serum LH levels were measured by ELISA. Total RNA was isolated from the pituitary gland to make cDNA to examine the expression of Gluts gene expression using real-time PCR analysis. GnRH treatment increased Glut1 mRNA levels 2.6-fold in prepubertal mice compared to vehicle-treated
Glut1 levels (Fig. 6A, $P<0 \cdot 001)$. There was no significant change in Glut2, -4 , or -8 mRNA levels in GnRH-treated mice compared to vehicle-treated mice (Fig. 6A). Serum LH levels increased 5-fold in GnRH-treated mice compared to vehicle-treated mice (Fig. 6B, $P<0 \cdot 05$ ).

\section{Discussion}

Our study is the first to show that GnRH stimulates glucose uptake in the pituitary gonadotroph cells in L $\beta$ T2 cells, which express several Gluts. This is a novel response of the gonadotroph cell to $\mathrm{GnRH}$, which has not been previously examined. Others have shown that increased uptake of $\left[{ }^{18} \mathrm{~F}\right] 2$-fluoro-2-deoxy-D-glucose in the pituitary gland of women was associated with estrogen-induced $\mathrm{LH}$ secretion (Ottowitz et al. 2008). Therefore, glucose uptake in the pituitary may serve as an important marker of energy metabolism that is important for the regulation of $\mathrm{LH}$ secretion.

Although others have shown that GnRH increases the expression of Glut1 mRNA gene expression (Wurmbach et al. 2001, Mazhawidza et al. 2006), we have additional studies that have examined the regulation of other Gluts mRNA and protein expression in L $\beta$ T2 gonadotroph cells. The activation of Glut1 by GnRH is acute with a maximal activation obtained by $2 \mathrm{~h}$ followed by a reduction in Glut 1 mRNA by $8 \mathrm{~h}$. Our studies were performed in serum containing media, which is known to rapidly degrade $\mathrm{GnRH}$, and this may account for the decrease in Glut expression in long-term culture. In contrast, the expression of Glut4 decreased after $8 \mathrm{~h}$ of $\mathrm{GnRH}$ treatment. GnRH had no significant effect on the expression of Glut2 or -8 in L $\beta$ T2
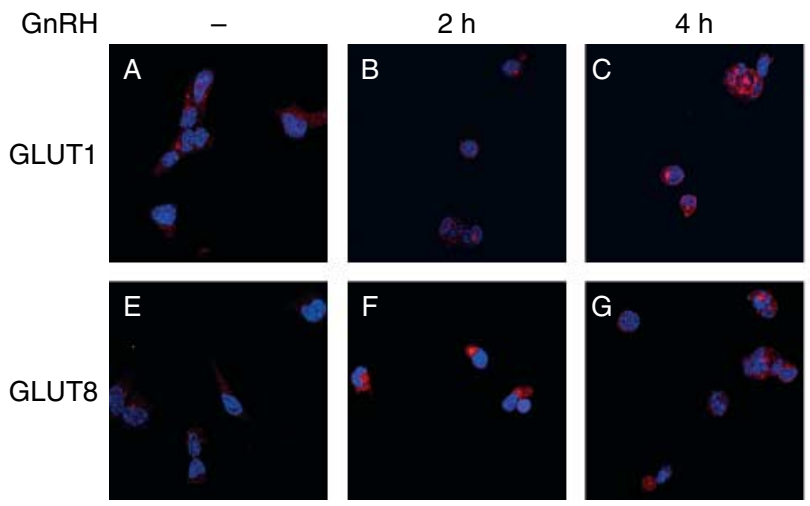

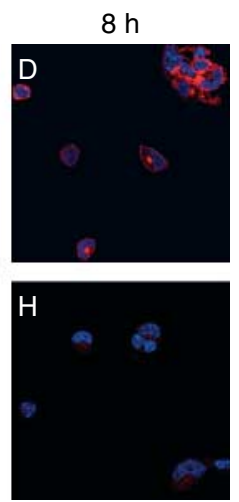

Figure $4 \mathrm{GnRH}$ induces translocation of GLUT1 protein in L $\beta T 2$ cells. L $\beta T 2$ cells were grown on Matrigel-coated coverslips in normal media and stimulated with $\mathrm{GnRH}$ $\left(100 \mathrm{M}^{-9}\right)$ for 2-8 h. Immunofluorescent analysis was performed with GLUT1 antibody (A, no GnRH, -), (B, GnRH at $2 \mathrm{~h}),(\mathrm{C}, \mathrm{GnRH}$ at $4 \mathrm{~h}),(\mathrm{D}, \mathrm{GnRH}$ at $8 \mathrm{~h})$ and GLUT8 antibody (E, no GnRH, -), (F, GnRH at $2 \mathrm{~h}),(\mathrm{G}, \mathrm{GnRH}$ at $4 \mathrm{~h})$, and $(\mathrm{H}, \mathrm{GnRH}$ at $8 \mathrm{~h})$ to show subcellular localization of glucose transporters. All images show merged GLUT1 or -8 immunofluorescence with DAPI nuclear staining. Images of cells viewed at $63 \times$ magnification with oil are shown. 


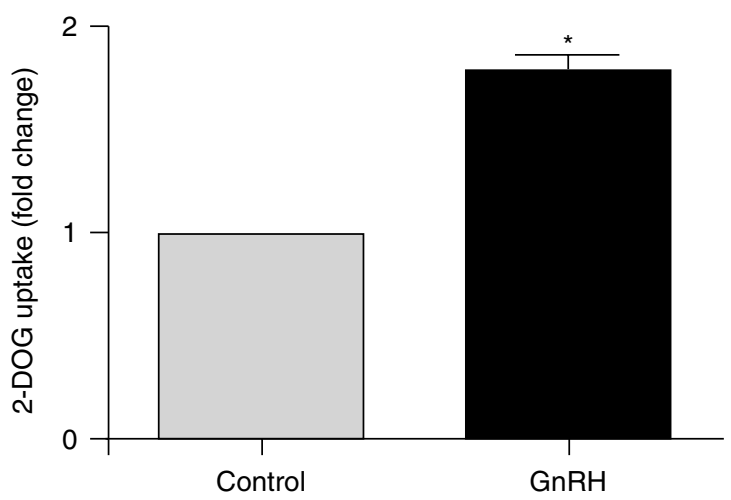

Figure $5 \mathrm{GnRH}$ stimulates glucose uptake in L $\beta T 2$ cells. L $\beta T 2$ cells were grown in normal media and stimulated with $\mathrm{GnRH}\left(100 \mathrm{M}^{-9}\right)$ or vehicle (media alone) for $4 \mathrm{~h}$. Glucose uptake assays were performed with 2-deoxy-D-[3H]-glucose (2-DOG). The graph represents the average of three experiments. In each experiment, there were four to six samples for control and four to six samples for $\mathrm{GnRH} .{ }^{*} P<0.05 \mathrm{GnRH}$ compared to control was determined by Mann-Whitney $U$ test.

cells. Therefore, GnRH differentially regulates the expression of Gluts in L $\beta$ T2 cells.

The regulation of Glut 1 gene expression by GnRH was further examined by using inhibitors of transcription and MAPK signaling. The acute increase in Glut1 expression induced by GnRH in L $\beta T 2$ cells was completely blocked by actinomycin $\mathrm{D}$, an inhibitor of transcription. Therefore, GnRH stimulates Glut $1 \mathrm{mRNA}$ by increasing gene transcription without affecting Glut $1 \mathrm{mRNA}$ stability. These results are consistent with other reports that enhanced gene transcription is one mechanism by which Glut1 expression is regulated (Kitagawa et al. 1991, Kozlovsky et al. 1997, Fong et al. 2004, Abdul Muneer et al. 2011). Our study also showed that induction of MAPK signaling is involved in mediating effects of GnRH on Glut1 gene expression in L $\beta T 2$ cells. Several studies have shown that ERK signaling is important for mediating effects of $\mathrm{GnRH}$ on gene expression and gonadotroph function (Roberson et al. 1995, Liu et al. 2002, Bliss et al. 2009, 2010). In addition, ERK activation is also important for the regulation of Glut1 gene expression in different tissues (Montessuit \& Thorburn 1999, Fong et al. 2001, Nose et al. 2003, Santalucia et al. 2003). In our study, the activation of Glut1 gene expression by GnRH is partly dependent on MEK activation. Lack of complete inhibition of GnRH-stimulated Glut1 expression by the MEK inhibitor U0126 suggests that other GnRH-induced signaling pathways are also involved in mediating effects of $\mathrm{GnRH}$ on Glut 1 gene expression in the gonadotroph.

To further examine the functional significance of $\mathrm{GnRH}-$ induced Glut 1 mRNA expression, we also examined the effect of GnRH on GLUT1 translocation. Our study shows that GnRH increases GLUT1 translocation to the cell surface. However, our study did not show that GnRH-induced translocation is independent of an effect of GnRH on Glut1 transcription because our immunofluorescent studies were not done in the presence of actinomycin D. Still, the increased detection of GLUT1 at the cell surface correlates with GnRH-stimulated glucose uptake. Although in most cells GLUT1 primarily mediates basal glucose uptake, studies have shown that in cardiac myocytes insulin stimulates translocation of GLUT1 to the plasma membrane and thus GLUT1 plays a role in insulin-stimulated glucose uptake in cardiac myocytes (Rett et al. 1996, Egert et al. 1999). Therefore, L $\beta T 2$ gonadotroph cells mediate responses to GnRH that impact glucose uptake and translocation of GLUTs.

The L $\beta$ T2 cell line, which was derived from a gonadotroph tumor that expresses SV40 T antigen, has served as a very useful in vitro model for examining the effects of $\mathrm{GnRH}$ and other hormones on pituitary gonadotroph function (Thomas et al. 1996, Turgeon et al. 1996). We have now shown that
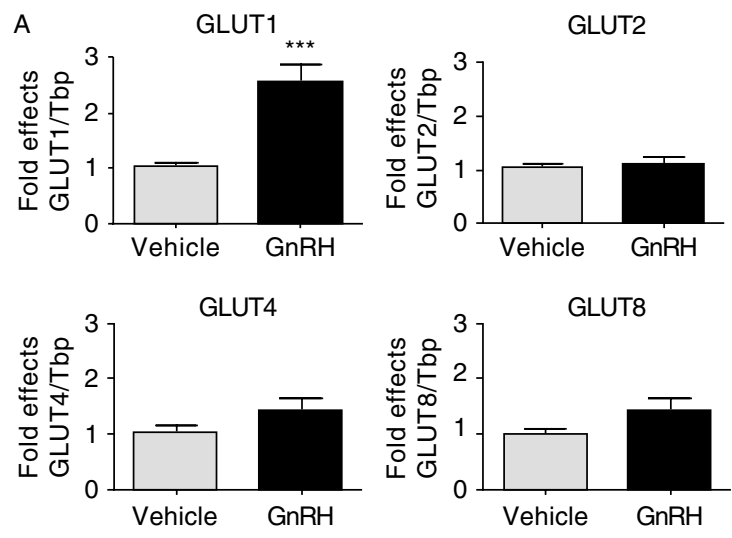

B

LH

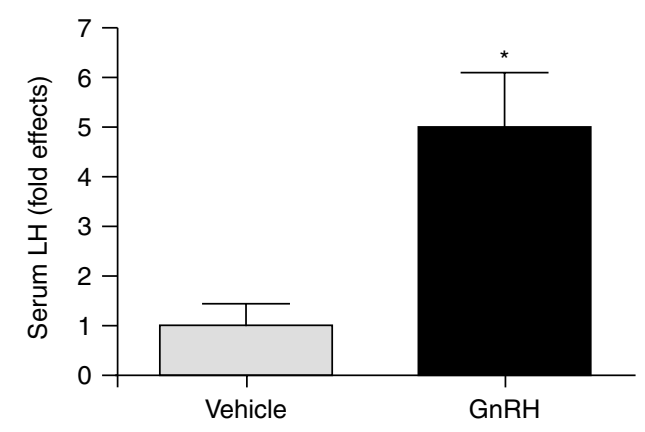

Figure $6 \mathrm{GnRH}$ stimulates Glut1 expression in the mouse pituitary gonadotroph. (A) C57/Bl6 prepubertal male and female mice were given GnRH i.p. injection and 60-90 min later pituitary glands were collected. Total RNA was isolated from the pituitary gland and real-time PCR analysis was performed on pituitary RNA isolated form prepubertal vehicle-treated mice (15-16 mice) and prepubertal $\mathrm{GnRH}$-treated mice (16-17 mice). Student's $t$-test was performed with *** indicating $P$ value $<0.001$ for $\mathrm{GnRH}$-treated mice compared to vehicle-treated mice. (B) C57BL/6J prepubertal male and female mice were given $\mathrm{GnRH}$ i.p. injection, and blood was collected 60-90 min later. LH immunoassays were performed with serum from prepubertal vehicle-treated mice (four mice) and prepubertal GnRH-treated mice (eight mice). Student's $t$-test was performed with * indicating $P$ value $<0.05$ for $\mathrm{GnRH}$-treated mice compared to vehicle-treated mice. 
these cells can also serve as an in vitro model to investigate changes in glucose metabolism in the gonadotroph. We speculate that the regulation of glucose metabolism by $\mathrm{GnRH}$ in the gonadotroph may play an important role in the synthesis and secretion of gonadotrophins.

Our study also investigated the regulation of Glut1 expression in the pituitary gland of prepubertal mice after treatment with exogenous GnRH. We used prepubertal mice because GnRH levels are known to increase after puberty. GnRH-induced Glut1 mRNA upregulation in gonadotrophs occurs under conditions that also increased serum LH levels in both female and male mice. Therefore, this data provides in vivo support of results in $\mathrm{L} \beta \mathrm{T} 2$ cells that $\mathrm{GnRH}$ regulates Glut 1 mRNA expression but not Glut2, -4 , or -8 in the pituitary gonadotroph.

Finally, it is well known that disorders of pubertal development and infertility, e.g. precocious puberty and polycystic ovary syndrome, are associated with obesity and type 2 diabetes mellitus. The data from our study shows that $\mathrm{GnRH}$ increased glucose utilization in the gonadotroph, and this indicates that in the gonadotroph $\mathrm{GnRH}$ regulates both glucose metabolism and gonadotrophin synthesis and secretion. Therefore, this study provides a foundation to further investigate the role of glucose utilization in the gonadotroph which may provide new insights into our understanding of disorders of the reproductive axis that are associated with abnormal glucose metabolism.

\section{Declaration of interest}

The authors declare that there is no conflict of interest that could be perceived as prejudicing the impartiality of the research reported.

\section{Funding}

This work was supported in part by NIH NIDDK grant (grant number KO8DK069518) and funding from Children's Hospital of Michigan, Pediatrics Department of Wayne State University School of Medicine and Texas Children's Hospital, Pediatrics Department of Baylor College of Medicine.

\section{Acknowledgements}

The authors thank P Mellon for providing L $\beta$ T2 cells, D Moore, L Karaviti, M Haymond, and A Gow, and J Benjamins for their useful suggestions and discussions, A Abbas for assistance with immunostaining studies, C Chandrasekera for technical advices, and R Thomas and M Dauod for assistance with statistical analyses.

\section{References}

Abdul Muneer PM, Alikunju S, Szlachetka AM, Murrin LC \& Haorah J 2011 Impairment of brain endothelial glucose transporter by methamphetamine causes blood-brain barrier dysfunction. Molecular Neurodegeneration 623. (doi:10.1186/1750-1326-6-23)
Barb CR, Kraeling RR \& Rampacek GB 1995 Glucose and free fatty acid modulation of growth hormone and luteinizing hormone secretion by cultured porcine pituitary cells. Journal of Animal Science 73 1416-1423.

Bliss SP, Miller A, Navratil AM, Xie J, McDonough SP, Fisher PJ, Landreth GE \& Roberson MS 2009 ERK signaling in the pituitary is required for female but not male fertility. Molecular Endocrinology 23 1092-1101. (doi:10. 1210/me.2009-0030)

Bliss SP, Navratil AM, Xie J \& Roberson MS 2010 GnRH signaling, the gonadotrope and endocrine control of fertility. Frontiers in Neuroendocrinology 31 322-340. (doi:10.1016/j.yfrne.2010.04.002)

Cagampang FR, Maeda KI, Tsukamura H, Ohkura S \& Ota K 1991 Involvement of ovarian steroids and endogenous opioids in the fastinginduced suppression of pulsatile LH release in ovariectomized rats. Journal of Endocrinology 129 321-328. (doi:10.1677/joe.0.1290321)

Cameron JL, Weltzin TE, McConaha C, Helmreich DL \& Kaye WH 1991 Slowing of pulsatile luteinizing hormone secretion in men after forty-eight hours of fasting. Journal of Clinical Endocrinology and Metabolism 73 35-41. (doi:10.1210/jcem-73-1-35)

Chappell PE, Schneider JS, Kim P, Xu M, Lydon JP, O’Malley BW \& Levine JE 1999 Absence of gonadotropin surges and gonadotropin-releasing hormone self-priming in ovariectomized (OVX), estrogen $\left(E_{2}\right)$-treated progesterone receptor knockout (PRKO) mice. Endocrinology 140 3653-3658. (doi:10.1210/en.140.8.3653)

Crane C, Akhter N, Johnson BW, Iruthayanathan M, Syed F, Kudo A, Zhou Y-H \& Childs GV 2007 Fasting and glucose effects on pituitary leptin expression. Is leptin a local signal for nutrient status? Journal of Histochemistry and Cytochemistry 55 1059-1073. (doi:10.1369/jhc.7A7214. 2007)

Egert S, Nguyen N \& Schwaiger M 1999 Myocardial glucose transporter GLUT1: translocation induced by insulin and ischemia. Journal of Molecular and Cellular Cardiology 31 1337-1344. (doi:10.1006/jmcc.1999.0965)

Fong JC, Kao YS, Tsai H \& Ho LT 2001 Endothelin-1 increases glucose transporter glut1 mRNA accumulation in 3T3-L1 adipocytes by a mitogen-activated protein kinase-dependent pathway. Cellular Signalling 13 491-497. (doi:10.1016/S0898-6568(01)00174-7)

Fong JC, Kao YS, Tsai HY, Chiou YY \& Chiou GY 2004 Synergistic effect of endothelin-1 and cyclic AMP on glucose transport in 3T3-L1 adipocytes. Cellular Signalling 16 811-821. (doi:10.1016/j.cellsig.2003.12.004)

Foster DL \& Olster DH 1985 Effect of restricted nutrition on puberty in the lamb: patterns of tonic luteinizing hormone $(\mathrm{LH})$ secretion and competency of the LH surge system. Endocrinology 116 375-381. (doi:10. 1210/endo-116-1-375)

Frolova A, Flessner L, Chi M, Kim ST, Foyouzi-Yousefi N \& Moley KH 2009 Facilitative glucose transporter type 1 is differentially regulated by progesterone and estrogen in murine and human endometrial stromal cells. Endocrinology 150 1512-1520. (doi:10.1210/en.2008-1081)

Guillam MT, Dupraz P \& Thorens B 2000 Glucose uptake, utilization, and signaling in GLUT2-null islets. Diabetes 49 1485-1491. (doi:10.2337/ diabetes.49.9.1485)

Hajduch E, Hainault I, Meunier C, Jardel C, Hainque B, Guerre-Millo M \& Lavau M 1995 Regulation of glucose transporters in cultured rat adipocytes: synergistic effect of insulin and dexamethasone on GLUT4 gene expression through promoter activation. Endocrinology 136 4782-4789. (doi:10.1210/ en.136.11.4782)

Haney PM, Levy MA, Strube MS \& Mueckler M 1995 Insulin-sensitive targeting of the GLUT4 glucose transporter in L6 myoblasts is conferred by its COOH-terminal cytoplasmic tail. Journal of Cell Biology 129 641-658. (doi:10.1083/jcb.129.3.641)

Howland BE 1980 Effect of glucoprivation induced by 2-deoxy-D-glucose on serum gonadotropin levels, pituitary response to $\mathrm{GnRH}$ and progesteroneinduced release of luteinizing hormone in rats. Hormone and Metabolic Research 12 520-523. (doi:10.1055/s-2007-999190)

Kandror KV, Coderre L, Pushkin AV \& Pilch PF 1995 a Comparison of glucose-transporter-containing vesicles from rat fat and muscle tissues: evidence for a unique endosomal compartment. Biochemical Journal 307 $383-390$. 
Kandror KV, Stephens JM \& Pilch PF 19956 Expression and compartmentalization of caveolin in adipose cells: coordinate regulation with and structural segregation from GLUT4. Journal of Cell Biology 129 999-1006. (doi:10.1083/jcb.129.4.999)

Kitagawa T, Masumi A \& Akamatsu Y 1991 Transforming growth factor-beta 1 stimulates glucose uptake and the expression of glucose transporter mRNA in quiescent Swiss mouse 3T3 cells. Journal of Biological Chemistry 266 18066-18071.

Kozlovsky N, Rudich A, Potashnik R, Ebina Y, Murakami T \& Bashan N 1997 Transcriptional activation of the Glut1 gene in response to oxidative stress in L6 myotubes. Journal of Biological Chemistry 272 33367-33372. (doi:10.1074/jbc.272.52.33367)

Kozma L, Baltensperger K, Klarlund J, Porras A, Santos E \& Czech MP 1993 The ras signaling pathway mimics insulin action on glucose transporter translocation. PNAS 90 4460-4464. (doi:10.1073/pnas.90.10.4460)

Kraus S, Naor Z \& Seger R 2001 Intracellular signaling pathways mediated by the gonadotropin-releasing hormone $(\mathrm{GnRH})$ receptor. Archives of Medical Research 32 499-509. (doi:10.1016/S0188-4409(01)00331-9)

Liu F, Austin DA, Mellon PL, Olefsky JM \& Webster NJ 2002 GnRH activates ERK1/2 leading to the induction of $\mathrm{c}-$ fos and LHbeta protein expression in LbetaT2 cells. Molecular Endocrinology 16 419-434. (doi:10.1210/me.16.3. 419)

Lu L, Lundqvist A, Zeng CM, Lagerquist C \& Lundahl P 1997 D-glucose, forskolin and cytochalasin B affinities for the glucose transporter Glut1. Study of $\mathrm{pH}$ and reconstitution effects by biomembrane affinity chromatography. Journal of Chromatography. A 776 81-86. (doi:10.1016/ S0021-9673(97)00151-9)

Maher F, Vannucci SJ \& Simpson IA 1994 Glucose transporter proteins in brain. FASEB Journal 8 1003-1011.

Marsh BJ, Alm RA, McIntosh SR \& James DE 1995 Molecular regulation of GLUT-4 targeting in 3T3-L1 adipocytes. Journal of Cell Biology 130 1081-1091. (doi:10.1083/jcb.130.5.1081)

Mazhawidza W, Winters SJ, Kaiser UB \& Kakar SS 2006 Identification of gene networks modulated by activin in LbetaT2 cells using DNA microarray analysis. Histology and Histopathology 21 167-178.

Montessuit C \& Thorburn A 1999 Transcriptional activation of the glucose transporter GLUT1 in ventricular cardiac myocytes by hypertrophic agonists. Journal of Biological Chemistry 274 9006-9012. (doi:10.1074/jbc. 274.13.9006)

Mueckler M 1994 Facilitative glucose transporters. European Journal of Biochemistry 219 713-725. (doi:10.1111/j.1432-1033.1994.tb18550.x)

Murahashi K, Bucholtz DC, Nagatani S, Tsukahara S, Tsukamura H, Foster DL \& Maeda KI 1996 Suppression of luteinizing hormone pulses by restriction of glucose availability is mediated by sensors in the brain stem. Endocrinology 137 1171-1176. (doi:10.1210/en.137.4.1171)

Nagatani S, Bucholtz DC, Murahashi K, Estacio MA, Tsukamura H, Foster DL \& Maeda KI 1996 Reduction of glucose availability suppresses pulsatile luteinizing hormone release in female and male rats. Endocrinology $\mathbf{1 3 7}$ 1166-1170. (doi:10.1210/en.137.4.1166)

Nagatani S, Zeng Y, Keisler DH, Foster DL \& Jaffe CA 2000 Leptin regulates pulsatile luteinizing hormone and growth hormone secretion in the sheep. Endocrinology 141 3965-3975. (doi:10.1210/en.141.11.3965)

Nose A, Mori Y, Uchiyama-Tanaka Y, Kishimoto N, Maruyama K, Matsubara H \& Iwasaka T 2003 Regulation of glucose transporter (GLUT1) gene expression by angiotensin II in mesangial cells: involvement of HB-EGF and EGF receptor transactivation. Hypertension Research 26 67-73. (doi:10. 1291/hypres.26.67)
Ohkura S, Ichimaru T, Itoh F, Matsuyama S \& Okamura H 2004 Further evidence for the role of glucose as a metabolic regulator of hypothalamic gonadotropin-releasing hormone pulse generator activity in goats. Endocrinology 145 3239-3246. (doi:10.1210/en.2003-1516)

Ottowitz WE, Dougherty DD, Fischman AJ \& Hall JE $2008\left[{ }^{18} \mathrm{~F}\right] 2$-fluoro-2deoxy-D-glucose positron emission tomography demonstration of estrogen negative and positive feedback on luteinizing hormone secretion in women. Journal of Clinical Endocrinology and Metabolism 93 3208-3214. (doi:10.1210/jc.2008-0203)

Rett K, Wicklmayr M, Dietze GJ \& Haring HU 1996 Insulin-induced glucose transporter (GLUT1 and GLUT4) translocation in cardiac muscle tissue is mimicked by bradykinin. Diabetes 45 (Suppl 1) S66-S69.

Roberson MS, Misra-Press A, Laurance ME, Stork PJ \& Maurer RA 1995 A role for mitogen-activated protein kinase in mediating activation of the glycoprotein hormone alpha-subunit promoter by gonadotropin-releasing hormone. Molecular and Cellular Biology 15 3531-3539.

Santalucia T, Christmann M, Yacoub MH \& Brand NJ 2003 Hypertrophic agonists induce the binding of c-Fos to an AP-1 site in cardiac myocytes: implications for the expression of GLUT1. Cardiovascular Research $\mathbf{5 9}$ 639-648. (doi:10.1016/S0008-6363(03)00472-3)

Schreihofer DA, Amico JA \& Cameron JL 1993 Reversal of fasting-induced suppression of luteinizing hormone $(\mathrm{LH})$ secretion in male rhesus monkeys by intragastric nutrient infusion: evidence for rapid stimulation of $\mathrm{LH}$ by nutritional signals. Endocrinology 132 1890-1897. (doi:10.1210/en.132. 5.1890)

Schreihofer DA, Renda F \& Cameron JL 1996 Feeding-induced stimulation of luteinizing hormone secretion in male rhesus monkeys is not dependent on a rise in blood glucose concentration. Endocrinology 137 3770-3776. (doi:10.1210/en.137.9.3770)

Sen KK, Azhar S \& Menon KM 1979 Evidence for the involvement of an energy-dependent process in gonadotropin-releasing hormone-stimulated luteinizing hormone release by rat anterior pituitary. Endocrinology 105 1158-1161. (doi:10.1210/endo-105-5-1158)

Stenbit AE, Tsao TS, Li J, Burcelin R, Geenen DL, Factor SM, Houseknecht K, Katz EB \& Charron MJ 1997 GLUT4 heterozygous knockout mice develop muscle insulin resistance and diabetes. Nature Medicine $\mathbf{3}$ 1096-1101. (doi:10.1038/nm1097-1096)

Thomas P, Mellon PL, Turgeon J \& Waring DW 1996 The L beta T2 clonal gonadotrope: a model for single cell studies of endocrine cell secretion. Endocrinology 137 2979-2989. (doi:10.1210/en.137.7.2979)

Turgeon JL, Kimura Y, Waring DW \& Mellon PL 1996 Steroid and pulsatile gonadotropin-releasing hormone $(\mathrm{GnRH})$ regulation of luteinizing hormone and GnRH receptor in a novel gonadotrope cell line. Molecular Endocrinology 10 439-450. (doi:10.1210/me.10.4.439)

Uldry M \& Thorens B 2004 The SLC2 family of facilitated hexose and polyol transporters. Pflügers Archiv 447 480-489. (doi:10.1007/s00424-003-1085-0)

Wurmbach E, Yuen T, Ebersole BJ \& Sealfon SC 2001 Gonadotropinreleasing hormone receptor-coupled gene network organization. Journal of Biological Chemistry 276 47195-47201. (doi:10.1074/jbc.M108716200)

Zhou J, Bievre M \& Bondy CA 2000 Reduced GLUT1 expression in Igf1 - / - null oocytes and follicles. Growth Hormone \& IGF Research 10 111-117. (doi:10.1054/ghir.2000.0147)

Received in final form 17 November 2011

Accepted 22 November 2011 Made available online as an Accepted Preprint 22 November 2011 